\title{
The occurrence of Dickinsonia in non-marine facies
}

\section{La aparición de Dickinsonia en facies no marinas}

\author{
N.I. Bobkov ${ }^{1,2}$, A.V. Kolesnikov ${ }^{1,3,4}$, A.V. Maslov ${ }^{3,5}$, D.V. Grazhdankin ${ }^{1,2}$ \\ ${ }^{1}$ Trofimuk Institute of Petroleum Geology and Geophysics of Siberian Branch of Russian Academy of Sciences, Koptuga 3 , \\ 630090 Novosibirsk, Russia. Email: nbobkov2011@yandex.ru; ORCID ID: https://orcid.org/0000-0003-1876-6445, https:// \\ orcid.org/0000-0003-1028-9082, https://orcid.org/0000-0003-0797-1347 \\ ${ }^{2}$ Novosibirsk State University, Pirogova 2, 630090 Novosibirsk, Russia. \\ ${ }^{3}$ Geological Institute, Russian Academy of Sciences, Pygevsky 7,119017 Moscow, Russia. ORCID ID: https://orcid. \\ org/0000-0003-4902-5789 \\ ${ }^{4}$ Moscow State Pedagogical University, Faculty of Geography, Kibalchicha str. 16, Moscow 129626, Russia. \\ ${ }^{5}$ Zavaritsky Institute of Geology and Geochemistry of the Ural Branch of the Russian Academy of Sciences, Akademika \\ Vonsovskogo 15, 620016 Yekaterinburg, Russia.
}

\begin{abstract}
Dickinsonia in the central Urals occurs in a succession transitional from marginal marine to non-marine. Even within this sequence Dickinsonia appears to be restricted to the least marine facies interpreted as a coastal lagoon surrounded by tidal flats. Another puzzling aspect is the complete absence of other Ediacaran taxa that are usually found together with Dickinsonia in other fossil localities. In fact, the Sinii Kamen Member of the Cherny Kamen Formation yielded an assemblage of Ediacaran macrofossils including aspidellamorph and mawsonitomorph holdfasts, frondomorphs, palaeopascichnids, and concentric ring structures of microbial origin; however, fossils of Dickinsonia have never been found in this association.
\end{abstract}

Keywords: Dickinsonia; soft-bodied metazoan; continental environments; Ediacaran.

\section{RESUMEN}

En los Urales centrales, Dickinsonia se encuentra en medios de transición entre sustratos continentales y marinos marginales, generalmente de tipo laguna costera rodeada por llanuras mareales. Otro aspecto llamatico es la ausencia de otros taxones ediacáricos asociados con Dickinsonia, relativamente abundantes en otros medios. De hecho, el Miembro de Sinii Kamen de la Formación de Cherny Kamen ha librado una asociación de macrofósiles ediacáricos, que incluye anclajes de tipo aspidellamorfo y mawsonitomorfo, frondomorfos, palaeopascichnidos y estructuras en anillos concéntricos de origen microbiano, con los que no se asocia Dickinsonia.

Palabras clave: Dickinsonia; metazoo de cuerpo blando; ambiente continental; Ediacárico. 


\section{Introduction}

Dickinsonia is an iconic late Ediacaran taxon representing benthic macroscopic soft-bodied organisms of uncertain phylogenetic affinity. It occurs in the Flinders Ranges of South Australia, the Dniester Valley in Podolia and the Southeast White Sea area, in lithofacies that have conventionally been regarded as shallow marine. Dickinsonia has also been described from the central Urals; however, the depositional context of the fossiliferous strata remains elusive.

\section{Results}

The fossils are confined to a 144 m-thick fining upward succession referred to as the Konovalovka Member, which is part of the ca. 1300 m-thick Cherny Kamen Formation cropping out in the lower reaches of Sylvitsa River, the right tributary of the Chusovaya River (58 $01^{\circ} 04^{\prime \prime}$ N, 58 40'15” E). The Cherny Kamen Formation in general records a gradual transition from basinal mudstone and marine prodelta to lower/upper delta plain in a foreland basin setting (Grazhdankin et al., 2009). The Konovalovka Member consists of four facies associations: flaser-bedded sandstone (F1), hummockybedded sandstone (F2), biolaminated sanstone (F3), and wave-rippled sandstone (F4).

The Konovalovka Member commences with flaser-bedded sandstone facies association (Fig. 1; F1). The facies association comprises packages (0.03-2.7 m) of flaser-bedded sandstones, channelised sandstones $(0.04-2.0 \mathrm{~m})$, and intervals of thin-bedded siltstones $(0.02-3.2 \mathrm{~m})$. The channel casts consist of thin-, planar- and wave-bedded sandstone. The facies also includes occasional sandstone biolaminites $(0.2$ and $0.6 \mathrm{~m}$-thick intervals), thin-bedded and hummocky-stratified sandstone interbeds, soft sediment deformation structures, and intervals of thin-bedded siltstone and mudstone. Thin-bedded and channelised sandstones often have clusters of flat mudstone clasts preserved as lag deposit. In addition, some of the thin-bedded siltstone intervals (49.1-51.4 and 52.2-52.4 m) contain numerous carbonaceous compression macrofossils representing microbial mat fragments. The flaser-bedded sandstone facies association is interpreted as a distal delta front depositional environment. The flaser-bedded sandstones prograde into hummocky-bedded sandstone facies association (Fig. 1; F2) consisting of interstratified parallel-laminated $(0.05-0.5 \mathrm{~m})$ and hummocky-bedded $(0.1-3.4 \mathrm{~m})$ sandstones. The parallel-laminated sandstones represent highenergy regime of intense bottom shear, whereas hummocky stratification suggests a combined flow regime in which storm-generated waves overprint hyperpycnal flows. The F2 facies association is interpreted as a proximal delta front depositional environment.

The biolaminated sandstone facies association (Fig. 1; F3) comprises intervals ( $0.2 \mathrm{~m}$ thick) of biolaminated sandstone, siltstone and mudstone interstratified with packages (0.03-3.4 m) of waverippled sandstone with siltstone and mudstone interbeds and intervals $(0.02-4.9 \mathrm{~m})$ of alternating siltstone and mudstone. Less common are waverippled, hummocky- and parallel-bedded sandstones, as well as occasional sandstone units with climbing ripple cross-lamination $(0.05-0.2 \mathrm{~m})$. The intervals of alternating siltstone and mudstone are characterised by desiccation cracks and salt crystal pseudomorphs. Microbial mats played a very important role in sediment stabilisation, which could explain the scarcity of clusters of flat mudstone clasts in this facies association. The F3 facies association is interpreted as a tidal flat depositional environment subject to episodic flooding and subaerial exposure.

The wave-rippled sandstone facies association (Fig. 1; F4) is sandwiched between two thick intervals of biolaminated sandstone. The facies association comprises intervals $(0.2-0.9 \mathrm{~m})$ of finely alternating wave-bedded sandstone, mudstone and siltstone interbeds interstratified with packages (0.05-1.4 m) of wave-rippled sandstones with finely laminated siltstone and mudstone interbeds. Occasionally, the facies also includes desiccation cracks and salt crystal pseudomorphs. The main difference from the biolaminated sandstone facies association is the ubiquitous wave-ripple lamination, which is interpreted as the result of slight increase in sediment input/reworking that suppressed microbial mat formation. The facies association F4 is here tentatively interpreted as a lagoon within a tidal flat 


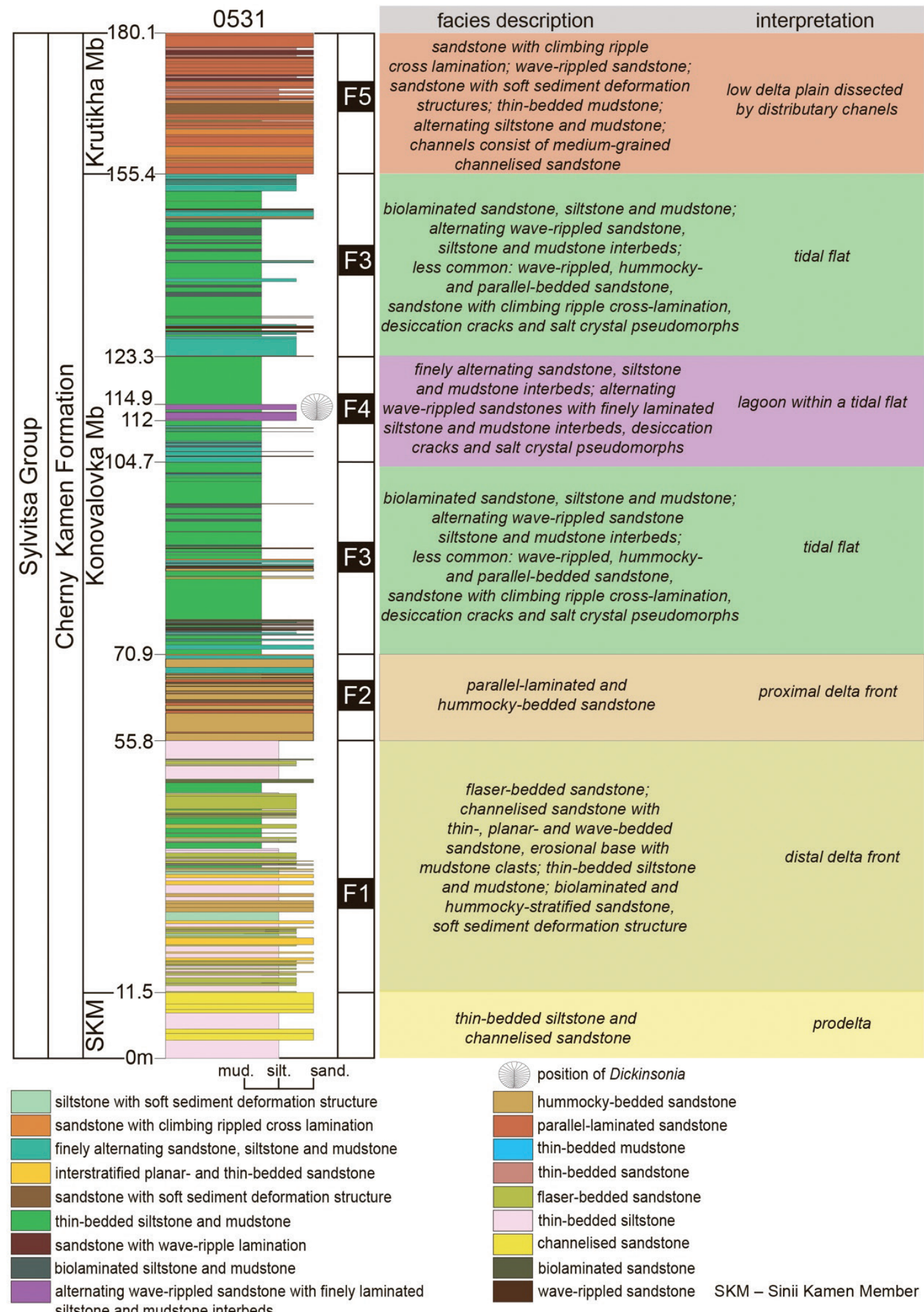

Figure 1.-Logged section of the Konovalovka Member along the Sylvitsa River showing facies associations and the position of Dickinsonia in non-marine depositional environments. 

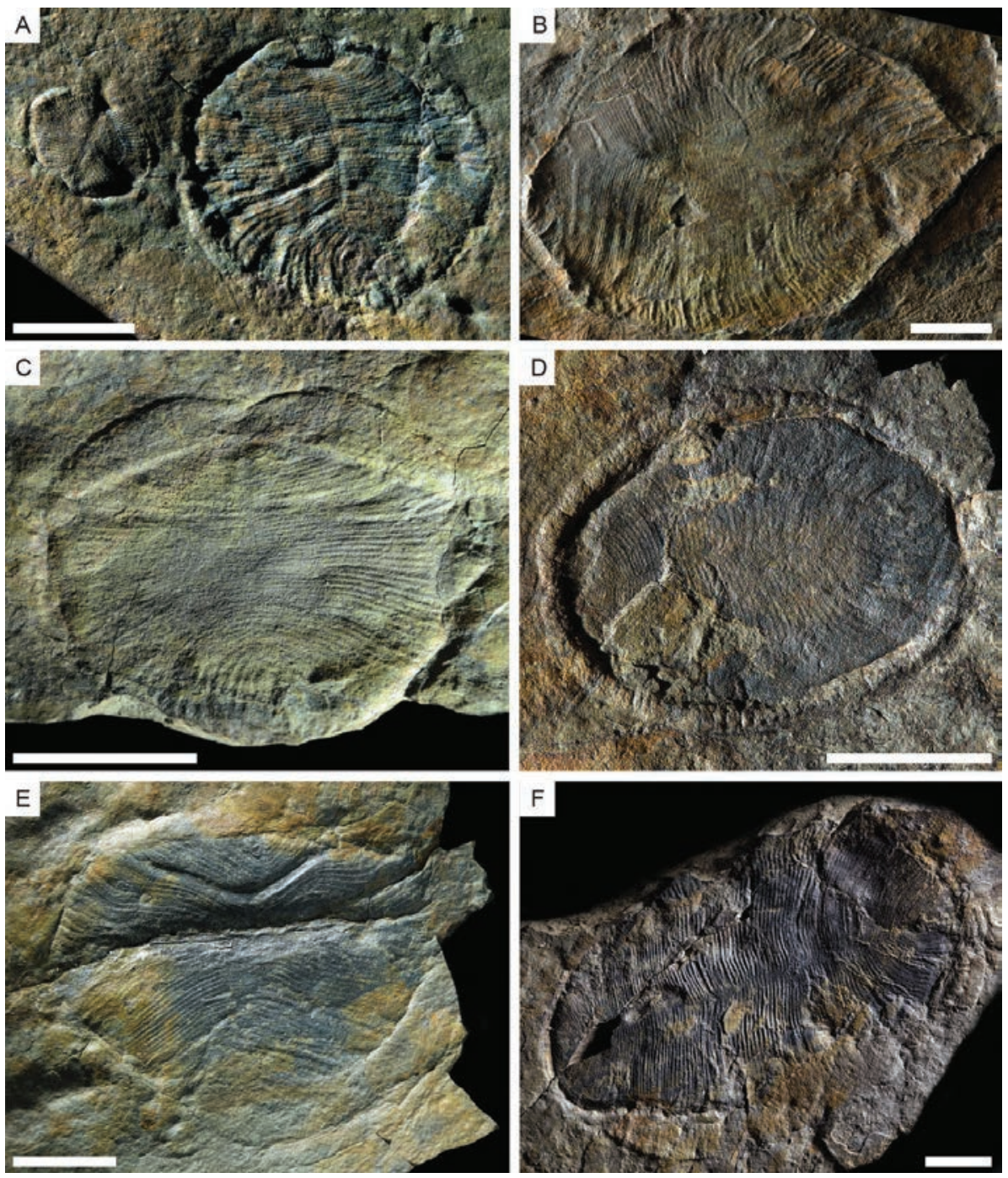

Figure 2.-Composite moulds of Dickinsonia from the Konovalovka Member of the Cherny Kamen Formation; specimens 205785.1,86.1 (A), 2057-84.2 (B), 2057-73.1 (C), 2057-72.2 (D), 2057-76.1 (E), 2057-197.2 (F). Scale bar = $1 \mathrm{~cm}$.

depositional environment, although the overall depositional setting of the biolaminated and wave-rippled sandstones facies is very similar. It is the waverippled sandstone facies association that yielded a numerically abundant assemblage of Dickinsonia preserved in situ (Sozonov et al., 2019) (Fig. 2).

The biolaminated sandstones of the Konovalovka Member are succeeded by the cross-bedded sandstone facies association of the Krutikha Member (Fig. 1; F5). The Krutikha Member of the Cherny Kamen Formation reaches $400 \mathrm{~m}$ in thickness and comprises multistoried cross-bedded sandstones regularly interstratified with intervals of fine alternating sandstone, siltstone and mudstone. The lithofacies is also characterised by broad channels up to $3.2-\mathrm{m}$ thick filled with medium-grained sandstones. The lowermost part of the channels exhibits coarse parallel and wavy bedding; the middle part consists of sandstones with multistoried unidirectional tabular cross-bedding; the uppermost part is trough crossbedded. The thickness of cross bedding varies between 1 and $7 \mathrm{~cm}$. The channels contain abundant clusters of flat mud pebbles in the lower part and along the cross-beds. Another distinctive feature of the facies is the abundance of diverse oscillation ripple marks, occasional salt crystal pseudomorphs, and casts of desiccation cracks. This facies association is interpreted as a result of the gradual progradation 
of a delta plain under high sediment supply regime (Grazhdankin et al., 2009).

\section{Conclusions}

In the central Urals, Dickinsonia occurs in a succession transitional from marginal marine to non-marine. Dickinsonia is restricted to coastal lagoon environments surrounded by tidal flats that have yielded no other Ediacaran taxa: e.g., the Sinii Kamen Member (Cherny Kamen Formation) has yielded an assemblage of Ediacaran macrofossils including aspidellamorph and mawsonitomorph holdfasts, frondomorphs, palaeopascichnids, and concentric ring structures of microbial origin; however, fossils of Dickinsonia have never been found in this association.

\section{ACKNOWLEDGEMENTS}

The stratigraphic and sedimentological studies were supported by the Russian Foundation for Basic Research grants 19-05-00927 and 19-05-00828. The findings and conclusions have immediate implications for understanding early evolution of Metazoa (Russian Science Foundation Grant 17-17-01241).

\section{References}

Grazhdankin, D.V.; Maslov, A.V. \& Krupenin, M.T. (2009). Structure and depositional history of the Vendian Sylvitsa Group in the western flank of the Central Urals. Stratigraphy and Geological Correlation, 17 (5): 475-492. https://doi.org/10.1134/ S0869593809050025

Sozonov, N.G.; Bobkov, N.I.; Mitchell, E.G.; Kolesnikov, A.V. \& Grazhdankin, D.V. (2019). The ecology of Dickinsonia on tidal flats. Estudios Geológicos, 75(2): e116. https://doi.org/10.3989/egeol.43587.571 